\title{
THE IMPACT OF DRY BAKER'S YEAST ON THE SUPPRESSION EFFECTS OF DIETARY AFLATOXIN ON SOME PRODUCTIVE, PHYSIOLOGICAL AND BEHAVIORAL TRAITS OF LAYING JAPANESE QUAIL
}

\author{
H. A. Khalil ${ }^{1}$ and M. Abdel-Razik ${ }^{2}$
}

1- Department of Animal Production, Faculty of Agriculture, Suez Canal University, Ismailia, Egypt, 2- Department of Microbiology, Faculty of Science, Suez Canal University, 41522 Ismailia, Egypt

\section{SUMMARY}

The present study was conducted to testify the impact of dry baker's yeast (DBY, Saccharomyces cerevisiae) on the suppression effects of aflatoxicosis in Japanese quail hens from 30 to 38 weeks of age. One hundred twenty quail hens were randomly divided into four groups: three treatments and one control (30 birds each of 3 replicates each). Control group was fed a basal diet while the treatment diets were supplemented with $D B Y(2 \mathrm{~g} / \mathrm{kg})$, aflatoxin $(A F, 3 \mathrm{mg} / \mathrm{kg})$ or $D B Y(2 \mathrm{~g} / \mathrm{kg})+A F$ (3 $\mathrm{mg} / \mathrm{kg})$. Body weight and mortality rate were recorded during the experimental period. Hen-day egg production, egg weight, egg mass, feed intake and feed conversion were evaluated throughout two intervals of laying period. After 4 and 8 wk from starting the treatment, 12 hens from each experimental group were slaughtered for blood collection and the livers were subjected to histopathological examination. Some hematological parameters (hemoglobin, hematocrit, red blood cells and white blood cells) were evaluated. Plasma total protein, albumen, total lipids, calcium, phosphorus, GOT, GPT, ALP and creatinine levels were analyzed. Also, some behavioral traits of females were recorded through the experimental work. The results confirmed that aflatoxin had significant negative effects on productive, physiological and behavioral traits during the experimental intervals. Quail hens fed diet contaminated with AF recorded the lowest values in most traits through the experimental period. In addition, dietary $D B Y$ had obvious positive effects on reducing the aflatoxicosis during the experimental intervals. Birds received $D B Y+A F$ exhibited significant improvement for most traits compared to those received AF only. Moreover, addition of DBY only to quail layer diet enhanced some traits but had no significant differences compared to control. Also, the results indicated that the experimental periods had a significant effect on most studied traits, especially in AF-treated group. Our findings strongly suggest that, the supplementation of laying quail's diet with the DBY had prophylactic effect on the performance of $A F$-treated birds via minimizing the harmful effects of toxin.

Keywords: Aflatoxin, Japanese quail, performance, blood components, behavioral traits, dry baker's yeast

Issued by The Egyptian Society of Animal Production 


\section{INTRODUCTION}

Aflatoxins are toxic fungal secondary metabolites of the genus Aspergillus (Betina, 1989). Intoxication of domestic birds by aflatoxin in experimental conditions results in reduced productive and reproductive performance (Leeson et al., 1995; Oliveira et al., 2002; Stanley et al., 2004; Arab Abousadi, 2007; Yildirim and Parlat, 2003), immunosuppression (Broomhead et al., 2002), changes in organs weight (Edds and Bortell, 1983), pathology of liver, kidney and spleen lesions (Glahn et al., 1991; Gokhan et al., 2006) and increased mortality rate (Leeson et al., 1995). Japanese quail was reported to be affected with aflatoxin exposure. Aflatoxin caused reduction in body weight, weight gain, feed intake, feed conversion, egg production, fertility and hatchability (Sawhney et al., 1973; Johri et al., 1990; Oliveira et al., 2002 and Parlat, 2003) and liver and kidney pathology (Gokhan et al., 2004). For minimizing the aflatoxin effects on performance of the toxin exposed birds, physical, chemical and biological treatments were used (Anderson, 1983; Miazzo et al., 2000; Muzaffer et al., 2003; Gokhan et al., 2006 and Baptista et al., 2008). One of the biological methods is supplementation of diet with yeast. Also, it was reported that adding yeast to aflatoxin contaminated feed might improve the birds performance via minimizing the harmful effects of toxin (Yildirim and Parlat, 2003 and Stanley et al., 2004). In spite of the excessive research on effects of aflatoxin on domestic poultry performance, there was fewer works dealing with the relationship among aflatoxin, yeast and productive performance and behavioural traits in laying Japanese quail. Therefore, this study was planned to examine the effects of dry baker's yeast (Saccharomyces cerevisiae) on the productive, physiological and behavioral traits of Japanese quail hens fed a diet contaminated with aflatoxin.

\section{MATERIALS AND METHODS}

\section{Birds and Housing:}

The present study was carried out at the Poultry Farm, Department of Animal Production, Faculty of Agriculture, Suez Canal University and at Microbiology Laboratory, Faculty of Science, Ismailia, Egypt. One hundred twenty 30-wk-old Japanese quail hens were individually weighed and randomly distributed into 4 experimental groups, three treatments and one control (30 birds each of 3 replicates each). The birds were kept in cages $(100 \times 50 \times 40 \mathrm{~cm})$ and given $16 \mathrm{hrs}$ light/day through the experiment period. Feed and water were offered ad libitum for all the experimental groups.

\section{Preparation and Administration of Aflatoxin:}

Sampling: Samples of poultry feeds were collected, homogenized and mixed together, and their moisture content was measured immediately. Ten grams of the samples were dried in an forced air oven for $16 \mathrm{hrs}$ at $80^{\circ} \mathrm{C}$, then weighed and the initial water contained was determined, as humidity percent $(19.2 \%)$ is essential for fungal propagation.

Fungus Isolation and Toxin Production: Ten grams of each sample (feed) was mixed with $90 \mathrm{ml}$ of $0.1 \%$ peptone water solution, serial dilutions was made, then 0.1 $\mathrm{ml}$ aliquots were inoculated on Czapeck's agar with rosebengal, growing fungal colonies were isolated purified and identified according to (Raper and Fennel, 1965). The commonly isolated fungus Aspergillus flavus was grown on polished rice till fermentation occurred as described by West et al. (1973) and Kubena et al. (1990). 
Fermented rice toxin was performed using thin layer chromatography (TLC), after extraction of the toxin using according to Richard et al. (1993), aflatoxin determination was carried out using high performance liquid chromatography (HPLC) (AOAC, 1995). The AF within the fermented rice consisted of 80\% B1, 16\% $\mathrm{G} 1,3 \% \mathrm{~B} 2$, and $1 \% \mathrm{G} 2$ based on total concentration of $\mathrm{AF}$ in the rice powder. The rice powder was incorporated into the basal diet to provide the desired level of $3 \mathrm{mg}$ of $\mathrm{AF} / \mathrm{kg}$ of diet.

Experimental Diets and Treatments: Japanese quails were fed a conventional corn and soybean meal basal diet, formulated to meet all the nutritional requirements of laying quail according to specifications of the National Research Council (1994). Diet 1 was the control diet, diet 2 contained DBY only $(2 \mathrm{~g} / \mathrm{kg})$, diet 3 contained AF only $(3 \mathrm{mg} / \mathrm{kg})$ and diet 4 contained both DBY $(2 \mathrm{~g} / \mathrm{kg})$ and AF $(3 \mathrm{mg} / \mathrm{kg})$. Hens were provided the diets ad libitum for 8 weeks.

\section{Data Collection:}

Productive Traits: Individual live body weights, feed intake, egg number and egg weight were recorded and feed conversion ratio, egg production rate and egg mass were calculated weekly and also mortality rate was recorded during the experimental period.

Physiological Traits: At the end of 4 and 8 weeks of the treatment, 12 hens from each group were slaughtered by slitting the jugular vein. Blood samples were collected in heparinized tubes. Red blood cells (RBCs) and white blood cells (WBCs) were counted in fresh blood samples using hemocytometer (Hawkey and Dennett, 1989). Hemoglobin concentration was determined using hemometer (Tietz, 1982). Blood was withdrawn by Packed-cell volume (PCV) capillary tube and centrifuged at $600 \mathrm{rpm}$ for 15 minutes. Hematocrit values (PCV \%) were recorded directly (Winderobe, 1965). The blood samples were centrifuged at $3000 \mathrm{rpm}$ for $15 \mathrm{~min}$ and plasma obtained was stored at $-20^{\circ} \mathrm{C}$ for further analysis. Plasma total protein, albumen, total lipids, calcium, phosphorus, GOT (Glutamic oxaloacetic transaminase), GPT (Glutamic pyruvic transaminase), ALP (Alkaline phosphatase) and creatinine were determined by calorimetrically by using available commercial kits from Egyptian company for biotechnology (S.A.E.). The globulin values were calculated by subtracting the values of albumen from the corresponding values of total protein.

Histopathology of the Liver: Livers samples of the control and treated groups were immediately removed after slaughtering, fixed in $10 \%$ neutral formalin saline, dehydrated in serially ascending alcohol, embedded in paraffin wax. Samples were sectioned and stained with hematoxilin and eosin stains (Bancroft and Stevens, 1990). Sections were examined microscopically and elucidated.

Behavioral Traits: The behavioral traits of all the groups were under observation during the experimental work using a video camera. The behavioral traits were recorded one day a week ( $3 \mathrm{hrs} /$ day, the $1^{\text {st }} \mathrm{hr}$ at the morning, the $2^{\text {nd }} \mathrm{hr}$ at the afternoon and the $3^{\text {rd }} \mathrm{hr}$ at the night). From the video tapes, at 5 minutes interval (time sampling) the basic activities (percentage of birds standing, sitting or walking) and the additional activities (percentage of birds feeding, drinking or preening) were recorded. The obtained numbers were used to calculate as the percentage of birds observed for each trait. 


\section{Statistical Analysis:}

Data were analyzed using the General Linear Model (GLM) procedure of SAS (SAS Institute Inc., 1998). Least Square Means (LSM) were calculated and Least Square Differences (LSD) between means were tested. Two-way analysis of variance was carried out using the following model:

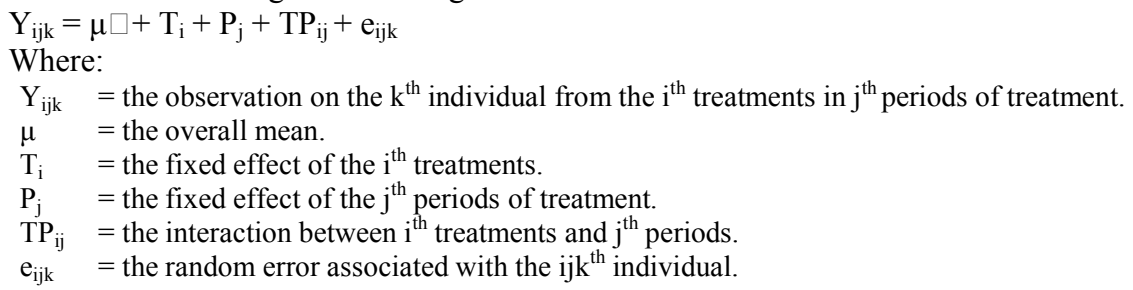

\section{RESULTS AND DISCUSSION}

\section{Productive Performance}

Live Body Weight and Mortality Rate: The initial body weight (30 weeks old) did not differ significantly among the treatment groups, indicating the complete randomization of distribution of birds into the experimental groups (Table 1). The final body weights at the end of experiment were significantly $(P \leq 0.05)$ lighter for quail group which fed diet contaminated with AF than others. Moreover, quail group which received diet contained AF recorded only mortality rate compared to other groups. Similar results were recorded by Johri et al. (1990); Doerr and Ottinger (1980); Chang and Hamilton (1982) who observed reduction in body weight of laying quails fed aflatoxin concentrations ranged from 500 to $10,000 \mu \mathrm{g} / \mathrm{kg}$ for 28 to 100 days. Also, Ogido et al. (2004) found that body weight reduced in quail hens fed diet contained $200 \mu \mathrm{g}$ of AFB1/ kg for 140 days. Furthermore, Gokhan et al. (2004) found that body weight was lowered in quail chicks fed diet contaminated with AF at $2.5 \mathrm{ppm}$ for 21 days compared to control chicks. Also, Muzaffer et al. (2003) recorded higher mortality rate in birds fed diet contaminated with aflatoxin than control birds.

On the other hand, the body weight was significantly increased in the group of birds which received DBY with AF compared to the group which received AF. These results are in agreement with those obtained by Parlat (2003); Santin et al. (2003) who found that live yeast and cell wall of live yeast at 1 to $2 \mathrm{~g} / \mathrm{kg}$ diet added with 2.5 to $5 \mathrm{mg} / \mathrm{kg}$ AF improved body weight in quail and broiler chicks. Also, Arab Abousadi et al. (2007) reported that addition of Saccharomyces cerevisiae at $2 \mathrm{~g} / \mathrm{kg}$ plus 125 ppb AF, improved body weight of broiler chicks. Finally, AL-Homidan and Fahmy (2007) found that added dried yeast to the basal diet of broiler chicks slightly increased the percentage of survivability compared to control group.

Egg Production Traits: All production traits were significantly affected by treatments during the different laying periods. Production rate, egg number, egg weight and egg mass were significantly $(P \leq 0.05)$ reduced following aflatoxin contamination to in the diet compared to untreated groups during the intervals or the entire period studied (Table 1). Our results are supported by that of Oliveira et al. (2002) who observed decreased egg weight in laying quail hens fed 50 or $100 \mu \mathrm{g}$ of AFB $1 / \mathrm{kg}$ for 168 days. Also, Stanley et al. (2004) reported that production rate of Comb broiler breeder was significantly lower for birds fed diets contaminated with 3 
$\mathrm{mg} / \mathrm{kg}$ AF for 3 weeks than control birds. Moreover, Ogido et al. (2004) observed that Japanese quail fed diets contained AFB1 at 50 to $200 \mu \mathrm{g} / \mathrm{kg}$ for 140 days showed losses in egg production.

Table 1. Effects of dry baker's yeast (DBY) in feed on some productive traits of quail hens fed diet contaminated with aflatoxin (AF)

\begin{tabular}{|c|c|c|c|c|}
\hline \multirow[t]{2}{*}{ Items } & \multicolumn{4}{|c|}{ Treatments } \\
\hline & Control & $\begin{array}{c}\text { DBY } \\
(2 \mathrm{~g} / \mathrm{kg})\end{array}$ & $\begin{array}{c}\mathrm{AF} \\
(3 \mathrm{mg} / \mathrm{kg})\end{array}$ & $\begin{array}{l}\text { DBY }(2 \mathrm{~g} / \mathrm{kg}) \\
+\mathrm{AF}(3 \mathrm{mg} / \mathrm{kg})\end{array}$ \\
\hline \multicolumn{5}{|c|}{ Body weight (g) } \\
\hline $\begin{array}{l}\text { Initial } \\
\text { weight }{ }^{1}\end{array}$ & $226.62 \pm 2.49$ & $227.25 \pm 2.47$ & $226.91 \pm 2.41$ & $229.41 \pm 2.39$ \\
\hline $\begin{array}{l}\text { Final } \\
\text { weight }^{2}\end{array}$ & $245.33 \pm 2.46^{\mathrm{a}}$ & $251.12 \pm 2.51^{\mathrm{a}}$ & $195.35 \pm 2.41^{\mathrm{c}}$ & $234.33 \pm 2.31^{b}$ \\
\hline Changes & $18.71 \pm 1.78^{\mathrm{a}}$ & $23.87 \pm 1.84^{\mathrm{a}}$ & $-31.56 \pm 1.92^{c}$ & $4.92 \pm 1.74^{b}$ \\
\hline \multicolumn{5}{|c|}{ Egg production rate } \\
\hline Period $\mathrm{I}^{3}$ & $83.14 \pm 2.37^{\mathrm{a}}$ & $86.25 \pm 2.39^{\mathrm{a}}$ & $57.69 \pm 2.48^{\mathrm{c}}$ & $72.43 \pm 2.12^{b}$ \\
\hline Period II ${ }^{4}$ & $71.46 \pm 2.84^{\mathrm{a}}$ & $75.82 \pm 2.17^{\mathrm{a}}$ & $39.11 \pm 2.08^{\mathrm{c}}$ & $66.18 \pm 2.61^{b}$ \\
\hline Overall & $77.31 \pm 1.67^{\mathrm{a}}$ & $81.03 \pm 1.74^{\mathrm{a}}$ & $48.41 \pm 1.65^{\mathrm{c}}$ & $69.32 \pm 1.56^{\mathrm{b}}$ \\
\hline \multicolumn{5}{|c|}{ Egg number/hen } \\
\hline Period I & $23.28 \pm 1.12^{\mathrm{a}}$ & $24.15 \pm 1.11^{\mathrm{a}}$ & $16.14 \pm 1.45^{\mathrm{c}}$ & $20.25 \pm 1.64^{b}$ \\
\hline Period II & $20.00 \pm 1.41^{\mathrm{a}}$ & $21.23 \pm 1.74^{\mathrm{a}}$ & $10.95 \pm 1.31^{\mathrm{c}}$ & $18.51 \pm 1.46^{\mathrm{b}}$ \\
\hline Total & $43.28 \pm 1.29^{\mathrm{a}}$ & $45.38 \pm 1.09^{\mathrm{a}}$ & $27.12 \pm 1.47^{\mathrm{c}}$ & $38.76 \pm 1.36^{b}$ \\
\hline \multicolumn{5}{|l|}{ Egg weight (g) } \\
\hline Period I & $12.46 \pm 0.35^{\mathrm{a}}$ & $12.54 \pm 0.34^{\mathrm{a}}$ & $10.25 \pm 0.28^{\mathrm{c}}$ & $11.87 \pm 0.37^{b}$ \\
\hline Period II & $12.63 \pm 0.29^{\mathrm{a}}$ & $12.89 \pm 0.37^{\mathrm{a}}$ & $9.13 \pm 0.24^{\mathrm{c}}$ & $11.57 \pm 0.38^{b}$ \\
\hline Overall & $12.54 \pm 0.26^{\mathrm{a}}$ & $12.72 \pm 0.21^{\mathrm{a}}$ & $9.69 \pm 0.20^{\mathrm{c}}$ & $11.72 \pm 0.25^{b}$ \\
\hline \multicolumn{5}{|c|}{ Egg mass (g/hen) } \\
\hline Period I & $290.11 \pm 12.12^{\mathrm{a}}$ & $302.85 \pm 11.14^{\mathrm{a}}$ & $165.45 \pm 12.09^{\mathrm{c}}$ & $240.37 \pm 11.95^{b}$ \\
\hline Period II & $253.61 \pm 12.07^{\mathrm{a}}$ & $273.67 \pm 12.45^{\mathrm{a}}$ & $99.98 \pm 11.92^{\mathrm{c}}$ & $214.13 \pm 11.67^{b}$ \\
\hline Total & $542.71 \pm 9.74^{\mathrm{a}}$ & $577.23 \pm 8.69^{a}$ & $265.42 \pm 9.69^{c}$ & $454.51 \pm 9.14^{\mathrm{b}}$ \\
\hline \multicolumn{5}{|c|}{ Feed intake (g/hen) } \\
\hline Period I & $850.51 \pm 6.13^{\mathrm{a}}$ & $845.45 \pm 6.42^{\mathrm{a}}$ & $709.12 \pm 5.94^{b}$ & $830.61 \pm 6.12^{\mathrm{a}}$ \\
\hline Period II & $826.11 \pm 6.24^{\mathrm{a}}$ & $805.67 \pm 6.75^{\mathrm{a}}$ & $520.48 \pm 6.19^{b}$ & $785.15 \pm 5.64^{\mathrm{a}}$ \\
\hline Total & $1677.62 \pm 4.35^{\mathrm{a}}$ & $1651.12 \pm 4.74^{\mathrm{a}}$ & $1229.61 \pm 5.12^{b}$ & $1615.76 \pm 5.37^{\mathrm{a}}$ \\
\hline \multicolumn{5}{|l|}{ G feed/g mass } \\
\hline Period I & $2.93 \pm 0.32^{b c}$ & $2.79 \pm 0.34^{\mathrm{c}}$ & $4.29 \pm 0.36^{\mathrm{a}}$ & $3.45 \pm 0.32^{\mathrm{b}}$ \\
\hline Period II & $3.27 \pm 0.30^{\mathrm{bc}}$ & $2.96 \pm 0.31^{\mathrm{c}}$ & $5.21 \pm 0.35^{\mathrm{a}}$ & $3.66 \pm 0.34^{\mathrm{b}}$ \\
\hline Overall & $3.09 \pm 0.21 \mathrm{bc}$ & $2.88 \pm 0.20^{\mathrm{c}}$ & $4.63 \pm 0.24^{\mathrm{a}}$ & $3.55 \pm 0.20^{\mathrm{b}}$ \\
\hline Total Mortality & $0 / 30$ & $0 / 30$ & $6 / 30$ & $0 / 30$ \\
\hline
\end{tabular}


However, the addition of DBY only at $2 \mathrm{~g} / \mathrm{kg}$ to quail diet enhanced egg production parameters but had no significant differences compared to control. In addition, hens fed DBY mixed with AF showed significant $(P \leq 0.05)$ improvement in all egg production parameters compared to those fed diet contaminated with AF throughout the entire experimental period. These findings are similar with results obtained by Stanley et al. (2004) who reported that yeast culture residue at $2 \mathrm{lb} / \mathrm{ton}$ supplementation to diet contained $\mathrm{AF}$ at $3 \mathrm{mg} / \mathrm{kg}$ significantly improved egg production of Comb broiler breeder. Also, Yildirim and Parlat (2003) reported that addition of Saccharomyces cerevisiae at $2 \mathrm{~g} / \mathrm{kg}$ to diet contaminated with $\mathrm{AF}$ at 5 $\mathrm{mg} / \mathrm{kg}$ of diet improved ovary weight of Japanese quail.

Feed Consumption and Feed Conversion Ratio: Data presented in Table 1 showed significant differences among experimental groups on feed consumption and feed conversion ratio. Concerning the intervals or the entire period studied, feed intake of birds received $\mathrm{AF}$ only was significantly $(P \leq 0.05)$ decreased compared to other groups. However, no significant variations were detected between control, DBY and AF plus DBY groups in total feed intake during the experimental periods. Also, the results cleared that quails fed diets contaminated with AF had the poorest feed conversion and least efficient feed utilization compared with the other groups.

Our results are in accordance with those of Sawhney et al. (1973) who noticed that feed conversion was adversely affected in quail exposed 2 to $6 \mathrm{mg} / \mathrm{kg}$ of AFB1 for 6 weeks. Also, Oliveira et al. (2002) reported that Japanese quail fed diets contained AFB1 above $50 \mu \mathrm{g} / \mathrm{kg}$ resulted reduction in feed intake. Also, Gokhan et al. (2004) found that quail chicks received diet contaminated with AF at $2.5 \mathrm{ppm}$ decreased feed consumption.

On the other hand, the addition of DBY only to quail layer diet improved feed conversion compared to control group but this improvement was not significant. In addition, the inclusion of DBY in the AF-treated diet significantly improved feed intake and feed conversion throughout the entire experimental period. These findings were observed by Parlat (2003) who found that yeast $(1 \mathrm{~g} / \mathrm{kg})$ supplemented to diet contaminated with AF $(2.5 \mathrm{mg} / \mathrm{kg})$ for quail chicks improved feed intake and feed conversion compared to AF diet, also with Santin et al. (2003) reported that addition of cell wall yeast to diet contaminated with mycotoxin improved feed conversion in broilers chicks. Data observed that productive traits were affected by the experimental periods especially in AF-treated group, which showed significantly reduction during the second period compared to the first period of laying. This result indicates that the toxin had a cumulative effect on the productive performance of the birds.

\section{Physiological Traits}

Plasma Biochemical Parameters: Compared with the control, feeding AF resulted in a significant decrease in all levels of plasma biochemicals assayed (total protein, albumin, globulin, total lipids, calcium and phosphorus) during the intervals or the entire period studied (Table 2). These results agree with those obtained by Gokhan et al. (2004) who reported that most biochemical values were significantly changed in quails after received $\mathrm{AF}$ at $2.5 \mathrm{ppm}$ for 21 days compared to controls. Also, Stanley et al. (2004) reported that concentrations of total protein, albumin, globulin, calcium, and phosphorus were significantly lower of broiler breeder hens that fed diets 
contaminated with $\mathrm{AF}$ at $3 \mathrm{mg} / \mathrm{kg}$. Similar findings were reported by Gokhan et al. (2006) who found that broiler chicks fed diet contaminated with 1 ppm AF for 42 days, decreased total protein and albumen compared to control group.

Table 2. Effects of dry baker's yeast (DBY) in feed on some plasma biochemical constituents of quail hens fed diet contaminated with aflatoxin (AF)

\begin{tabular}{|c|c|c|c|c|}
\hline \multirow[t]{2}{*}{ Items } & \multicolumn{4}{|c|}{ Treatments } \\
\hline & Control & $\begin{array}{c}\text { DBY } \\
(2 \mathrm{~g} / \mathrm{kg})\end{array}$ & $\begin{array}{c}\text { AF } \\
(3 \mathrm{mg} / \mathrm{kg})\end{array}$ & $\begin{array}{l}\text { DBY }(2 \mathrm{~g} / \mathrm{kg}) \\
+\mathrm{AF}(3 \mathrm{mg} / \mathrm{kg})\end{array}$ \\
\hline \multicolumn{5}{|c|}{ Total protein $(\mathrm{g} / \mathrm{dl})$} \\
\hline Period I ${ }^{1}$ & $5.61 \pm 0.59^{a}$ & $5.98 \pm 0.61^{\mathrm{a}}$ & $3.46 \pm 0.54^{b}$ & $5.20 \pm 0.61^{\mathrm{a}}$ \\
\hline Period $\mathrm{II}^{2}$ & $6.42 \pm 0.67^{\mathrm{a}}$ & $6.60 \pm 0.59^{a}$ & $3.01 \pm 0.61^{\mathrm{c}}$ & $4.69 \pm 0.63^{b}$ \\
\hline Overall & $6.02 \pm 0.28^{\mathrm{a}}$ & $6.29 \pm 0.32^{\mathrm{a}}$ & $3.23 \pm 0.28^{\mathrm{c}}$ & $4.94 \pm 0.32^{b}$ \\
\hline \multicolumn{5}{|c|}{ Albumen (g/dl) } \\
\hline Period I & $3.56 \pm 0.25^{\mathrm{a}}$ & $3.75 \pm 0.24^{\mathrm{a}}$ & $2.12 \pm 0.21^{\mathrm{c}}$ & $3.05 \pm 0.21^{b}$ \\
\hline Period II & $4.28 \pm 0.26^{\mathrm{a}}$ & $4.42 \pm 0.23^{\mathrm{a}}$ & $1.52 \pm 0.26^{\mathrm{c}}$ & $2.71 \pm 0.21^{b}$ \\
\hline Overall & $3.92 \pm 0.22^{\mathrm{a}}$ & $4.08 \pm 0.21^{\mathrm{a}}$ & $1.82 \pm 0.22^{\mathrm{c}}$ & $2.88 \pm 0.21^{b}$ \\
\hline \multicolumn{5}{|c|}{ Globulin $(g / d l)$} \\
\hline Period I & $2.05 \pm 0.12^{\mathrm{a}}$ & $2.23 \pm 0.14^{\mathrm{a}}$ & $1.34 \pm 0.16^{\mathrm{b}}$ & $2.15 \pm 0.14^{\mathrm{a}}$ \\
\hline Period II & $2.14 \pm 0.16^{\mathrm{a}}$ & $2.18 \pm 0.12^{\mathrm{a}}$ & $1.49 \pm 0.12^{b}$ & $1.98 \pm 0.12^{\mathrm{a}}$ \\
\hline Overall & $2.08 \pm 0.11^{\mathrm{a}}$ & $2.21 \pm 0.11^{\mathrm{a}}$ & $1.41 \pm 0.10^{b}$ & $2.06 \pm 0.11^{\mathrm{a}}$ \\
\hline \multicolumn{5}{|c|}{ Total lipids $(\mathrm{g} / \mathrm{l})$} \\
\hline Period I & $32.02 \pm 2.24^{\mathrm{a}}$ & $29.54 \pm 2.36^{\mathrm{a}}$ & $18.26 \pm 2.61^{\mathrm{c}}$ & $20.42 \pm 2.70^{b}$ \\
\hline Period II & $41.88 \pm 2.15^{\mathrm{a}}$ & $38.65 \pm 2.64^{\mathrm{a}}$ & $21.36 \pm 2.26^{\mathrm{c}}$ & $27.19 \pm 2.47^{\mathrm{b}}$ \\
\hline Overall & $36.95 \pm 1.58^{\mathrm{a}}$ & $34.09 \pm 1.37^{\mathrm{a}}$ & $19.81 \pm 1.27^{\mathrm{c}}$ & $23.80 \pm 1.94^{b}$ \\
\hline \multicolumn{5}{|c|}{ Calcium (mg/dl) } \\
\hline Period I & $8.62 \pm 0.29^{a}$ & $8.98 \pm 0.31^{\mathrm{a}}$ & $6.12 \pm 0.24^{\mathrm{c}}$ & $8.22 \pm 0.26^{\mathrm{a}}$ \\
\hline Period II & $8.29 \pm 0.24^{\mathrm{a}}$ & $8.56 \pm 0.31^{\mathrm{a}}$ & $4.16 \pm 0.34^{\mathrm{c}}$ & $6.85 \pm 0.29^{b}$ \\
\hline Overall & $8.45 \pm 0.21^{\mathrm{a}}$ & $8.77 \pm 0.20^{\mathrm{a}}$ & $5.14 \pm 0.18^{\mathrm{c}}$ & $7.53 \pm 0.21^{b}$ \\
\hline \multicolumn{5}{|c|}{ Phosphorus (mg/dl) } \\
\hline Period I & $4.98 \pm 0.34^{\mathrm{a}}$ & $4.81 \pm 0.37^{\mathrm{a}}$ & $3.00 \pm 0.29 b$ & $4.15 \pm 0.27^{b}$ \\
\hline Period II & $5.25 \pm 0.32^{\mathrm{a}}$ & $5.09 \pm 0.33^{\mathrm{a}}$ & $2.12 \pm 0.28^{\mathrm{c}}$ & $4.02 \pm 0.27^{b}$ \\
\hline Overall & $5.11 \pm 0.24^{\mathrm{a}}$ & $4.95 \pm 0.21^{\mathrm{a}}$ & $2.56 \pm 0.23^{\mathrm{c}}$ & $4.08 \pm 0.21 \mathrm{~b}$ \\
\hline
\end{tabular}

a,b,c,d Means \pm SE in a row with no common superscript differ significantly $(P \leq 0.05)$.

${ }^{1}$ Period I = After 4 wks from starting of the treatment ( $34 \mathrm{wks}$ of age).

${ }^{2}$ Period II $=$ After 4 wks from the first period (38 wks of age).

Furthermore, the addition of DBY to the diet containing AF improved the decline in plasma components during the experimental intervals. These results are in agreement with the results obtained by Stanley et al. (2004) who reported improvement in the depressed values of albumen and globulin following yeast supplemented to Comb broiler breeder diet. Also, Arab Abousadi et al. (2007) found 
that Saccharomyces cerevisiae at $2 \mathrm{~g} / \mathrm{kg}$ plus AF at $125 \mathrm{ppb}$ resulted in improvement against negative effects of AFB1 in total protein concentration in broiler chicks.

Blood Hematological Parameters: Significant $(P \leq 0.05)$ variations were found among experimental groups in all hematological parameters values $(\mathrm{Hb}, \mathrm{Ht}, \mathrm{RBCs}$ and WBCs) during the experimental intervals (Table 3). Quails fed diet contaminated with AF had the lowest values compared to other groups. Moreover, the addition of DBY to the diet contaminated with AF improved these parameters that were significantly higher than the AF-treated group except WBCs value which was significantly higher than all treated and control groups. This improvement agree with Kemal et al. (2003) who reported that immunity of broiler was improved when used baker yeast mixed with diet contained AFB1. Also with Tollba and El-Nagar (2008) found that supplemented live yeast to Egyptian local strain layers diet improved immunity compared to control birds.

Table 3. Effects of dry baker's yeast (DBY) in feed on some hematological parameters of quail hens fed diet contaminated with aflatoxin (AF)

\begin{tabular}{|c|c|c|c|c|}
\hline \multirow[t]{2}{*}{ Items } & \multicolumn{4}{|c|}{ Treatments } \\
\hline & Control & $\begin{array}{c}\text { DBY } \\
(2 \mathrm{~g} / \mathrm{kg})\end{array}$ & $\begin{array}{c}\text { AF } \\
(3 \mathrm{mg} / \mathrm{kg})\end{array}$ & $\begin{array}{c}\text { DBY(2g/kg) } \\
+\mathrm{AF}(3 \mathrm{mg} / \mathrm{kg})\end{array}$ \\
\hline \multicolumn{5}{|c|}{ Hemoglobin (g \%) } \\
\hline Period I ${ }^{1}$ & $12.02 \pm 0.41^{\mathrm{a}}$ & $11.82 \pm 0.45^{\mathrm{ab}}$ & $9.68 \pm 0.42^{\mathrm{c}}$ & $11.12 \pm 0.39^{b}$ \\
\hline Period $\mathrm{II}^{2}$ & $11.53 \pm 0.47^{\mathrm{a}}$ & $11.98 \pm 0.46^{\mathrm{a}}$ & $8.78 \pm 0.41^{\mathrm{c}}$ & $10.08 \pm 0.42^{b}$ \\
\hline Overall & $11.77 \pm 0.31^{\mathrm{a}}$ & $11.91 \pm 0.32^{\mathrm{a}}$ & $9.23 \pm 0.30^{\mathrm{c}}$ & $10.61 \pm 0.35^{b}$ \\
\hline \multicolumn{5}{|c|}{ Hematocrit (\%) } \\
\hline Period I & $40.54 \pm 1.19^{\mathrm{a}}$ & $39.45 \pm 1.14^{\mathrm{ab}}$ & $35.15 \pm 1.24^{\mathrm{c}}$ & $38.45 \pm 1.32^{b}$ \\
\hline Period II & $40.66 \pm 1.13^{\mathrm{a}}$ & $42.38 \pm 1.16^{\mathrm{a}}$ & $32.19 \pm 1.08^{\mathrm{c}}$ & $35.01 \pm 1.16^{\mathrm{b}}$ \\
\hline Overall & $40.61 \pm 0.85^{\mathrm{a}}$ & $40.91 \pm 0.82^{\mathrm{a}}$ & $33.67 \pm 0.79^{c}$ & $36.73 \pm 0.73^{b}$ \\
\hline \multicolumn{5}{|c|}{$R B C s\left(10^{6} \mathrm{Xml}\right)$} \\
\hline Period I & $2.45 \pm 0.04^{\mathrm{a}}$ & $2.56 \pm 0.02^{\mathrm{a}}$ & $2.11 \pm 0.02^{b}$ & $2.47 \pm 0.04^{\mathrm{a}}$ \\
\hline Period II & $2.81 \pm 0.02^{\mathrm{a}}$ & $2.89 \pm 0.03^{\mathrm{a}}$ & $1.86 \pm 0.03^{c}$ & $2.22 \pm 0.02^{b}$ \\
\hline Overall & $2.63 \pm 0.03^{\mathrm{a}}$ & $2.73 \pm 0.01^{\mathrm{a}}$ & $1.98 \pm 0.02^{\mathrm{c}}$ & $2.34 \pm 0.03^{b}$ \\
\hline \multicolumn{5}{|c|}{ WBCs $\left(10^{3} \mathrm{Xml}\right)$} \\
\hline Period I & $18.12 \pm 0.47^{\mathrm{b}}$ & $19.58 \pm 0.41^{b}$ & $15.42 \pm 0.39^{\mathrm{c}}$ & $22.36 \pm 0.45^{\mathrm{a}}$ \\
\hline Period II & $18.54 \pm 0.39^{b}$ & $20.34 \pm 0.41^{b}$ & $12.12 \pm 0.42^{\mathrm{c}}$ & $28.67 \pm 0.46^{\mathrm{a}}$ \\
\hline Overall & $18.33 \pm 0.33^{b}$ & $19.96 \pm 0.35^{\mathrm{b}}$ & $13.77 \pm 0.30^{\mathrm{c}}$ & $25.51 \pm 0.35^{\mathrm{a}}$ \\
\hline
\end{tabular}

Liver and kidney functions: Data in Table 4 show significant $(P \leq 0.001)$ effects of different treatments on liver and kidney functions during the different periods studied. Hens received AF only had the highest abnormal levels of GOT, GPT, ALP and creatinine compared to other groups during the experimental intervals of laying hens. On the other hand, diet with DBY plus AF showed significantly decreased plasma concentrations of GOT, GPT, ALP and creatinine compared to diet 
contaminated with AF group throughout the entire experimental period. The increasing of ALP, GOT and GPT levels are usually indicators of disfunction of hepatocellular damage. Similar findings were reported by Kemal et al. (2003) and Gokhan et al. (2004) who found that plasma concentrations of ALP, GOT, GPT and creatinine significantly changed in quails and broiler chicks received AF for 21-37 days of treatment, also with Gokhan et al. (2006) who reported that broiler chicks fed diet contaminated with $\mathrm{AF}$ at $1 \mathrm{ppm}$ for 42 days, increased plasma concentrations of GOT, GPT, ALP as compared to control birds. Moreover, Kemal et al. (2003) found that birds received baker yeast at $2 \%$ with diet contaminated with AFB1 improved liver function and decreased liver enzymes. Moreover, AF-treated group showed greatly changed $(P \leq 0.05)$ in all physiological traits during the second period compared to the first period of treatment. These changes showed as a decreasing in plasma biochemical and hematological parameters and increasing in liver enzymes concentrations. This result indicated that, the toxin had a cumulative effect on physiological status of the birds.

Table 4. Effects of dry baker's yeast (DBY) in feed on liver and kidney functions of quail hens fed diet contaminated with aflatoxin (AF)

\begin{tabular}{|c|c|c|c|c|}
\hline \multirow[t]{2}{*}{ Items } & \multicolumn{4}{|c|}{ Treatments } \\
\hline & Control & $\begin{array}{c}\text { DBY } \\
(2 \mathrm{~g} / \mathrm{kg})\end{array}$ & $\begin{array}{c}\text { AF } \\
(3 \mathrm{mg} / \mathrm{kg})\end{array}$ & $\begin{array}{c}\text { DBY(2g/kg) } \\
+\mathrm{AF}(3 \mathrm{mg} / \mathrm{kg})\end{array}$ \\
\hline \multicolumn{5}{|l|}{ GOT (IU/L) } \\
\hline Period I ${ }^{1}$ & $89.83 \pm 2.21^{\mathrm{c}}$ & $84.16 \pm 2.21^{\mathrm{c}}$ & $112.33 \pm 2.22^{\mathrm{a}}$ & $96.16 \pm 2.22 \mathrm{~b}$ \\
\hline Period $\mathrm{II}^{2}$ & $90.00 \pm 2.22^{\mathrm{c}}$ & $89.83 \pm 2.21^{\mathrm{c}}$ & $160.33 \pm 2.22^{\mathrm{a}}$ & $105.34 \pm 2.21^{b}$ \\
\hline Overall & $89.91 \pm 1.57^{\mathrm{c}}$ & $87.01 \pm 1.55^{\mathrm{c}}$ & $136.33 \pm 1.55^{\mathrm{a}}$ & $100.75 \pm 1.56^{b}$ \\
\hline \multicolumn{5}{|l|}{$G P T(I U / L)$} \\
\hline Period I & $14.26 \pm 1.96^{\mathrm{b}}$ & $14.23 \pm 1.95^{\mathrm{b}}$ & $20.34 \pm 1.94^{\mathrm{a}}$ & $16.82 \pm 1.95^{b}$ \\
\hline Period II & $14.02 \pm 1.94^{\mathrm{c}}$ & $13.67 \pm 1.94^{\mathrm{c}}$ & $31.61 \pm 1.95^{\mathrm{a}}$ & $20.19 \pm 1.96^{b}$ \\
\hline Overall & $14.15 \pm 0.87^{\mathrm{c}}$ & $13.95 \pm 0.88^{\mathrm{c}}$ & $25.92 \pm 0.85^{\mathrm{a}}$ & $18.51 \pm 0.87^{b}$ \\
\hline \multicolumn{5}{|l|}{$A L P(I U / L)$} \\
\hline Period I & $61.81 \pm 2.35^{\mathrm{c}}$ & $60.15 \pm 2.42^{c}$ & $81.36 \pm 2.36^{\mathrm{a}}$ & $68.63 \pm 2.54^{b}$ \\
\hline Period II & $65.69 \pm 2.26^{\mathrm{c}}$ & $64.45 \pm 2.37^{\mathrm{c}}$ & $93.64 \pm 2.16^{\mathrm{a}}$ & $71.94 \pm 2.51^{b}$ \\
\hline Overall & $63.75 \pm 1.66^{\mathrm{c}}$ & $62.3 \pm 1.36^{\mathrm{c}}$ & $87.52 \pm 1.94^{\mathrm{a}}$ & $70.28 \pm 1.26^{b}$ \\
\hline \multicolumn{5}{|c|}{ Creatinine (mg/dl) } \\
\hline Period I & $0.30 \pm 0.19^{b}$ & $0.34 \pm 0.18^{b}$ & $1.64 \pm 0.16^{\mathrm{a}}$ & $0.49 \pm 0.19^{b}$ \\
\hline Period II & $0.37 \pm 0.12^{b}$ & $0.35 \pm 0.14^{b}$ & $2.51 \pm 0.12^{\mathrm{a}}$ & $0.75 \pm 0.11^{b}$ \\
\hline Overall & $0.33 \pm 0.11^{\mathrm{b}}$ & $0.34 \pm 0.12^{b}$ & $2.07 \pm 0.12^{\mathrm{a}}$ & $0.62 \pm 0.11^{b}$ \\
\hline
\end{tabular}




\section{Histopathological Examination of the Liver}

Aflatoxin given at the dose of $3 \mathrm{mg} / \mathrm{kg}$ for 8 weeks caused extreme damage to the liver (Fig. 1). This damage was parallel to the changes in biochemical parameters. The aflatoxicated birds revealed pronounced histopathological changes in their livers. These changes were mainly represented by tissue degeneration and necrotic fatty vacuolation also hemorrhages and lymphocytes infiltration was evident. These results are consistent with reports of Oliveira et al. (2002) who reported that quail hens fed AFB1 at $100 \mu \mathrm{g} / \mathrm{kg}$ of diet showed hepatic cell vacuolation with fatty necrosis. Also, Gokhan et al. (2004 \& 2006) and Karaman et al. (2005) found that quail and broiler chicks fed diets contaminated with AF at $1-205$ ppm for 21 to 45 days caused extreme damage to the liver. In addition, aflatoxin caused hepatotoxicity, cellular disorganization, and hepatocyte necrosis in the Wistar rats (Baptista et al., 2008). Relative weight of liver in broiler chicks fed diet containing AFB1were significantly greater than control chicks (Arab Abousadi et al., 2007).

In our experiment, the supplementation with dry baker's yeast counteracted the $\mathrm{AF}$ intoxication and remarkably improved and minimized the liver damage in treated birds. Histological changes were minimal with the presence of inflammatory infiltration and almost similar to control birds. These results are similar to data reported by Santin et al. (2003) and Arab Abousadi et al. (2007) who found that Saccharomyces cerevisiae at 1 or $2 \mathrm{~g} / \mathrm{kg}$ improved relative weights of liver in broiler chicks fed diet contaminated with 125 or $500 \mathrm{ppb}$ of aflatoxin. Moreover, Karaman et al. (2005) showed that yeast glucomannan at $1 \mathrm{~g} / \mathrm{kg}$ plus $2 \mathrm{mg} / \mathrm{kg}$ AF had adverse effects of aflatoxin on the pathological changes of the liver. Also, Baptista et al. (2008) found that, yeast reduced the toxicity in the Wistar rats especially of liver pathology.

\section{Behavioral Traits}

Concerning the intervals or the entire period studied, basic behavioral activities (standing, sitting and walking) were significantly $(P \leq 0.05)$ affected by AF diet (Tables 5). Birds fed AF alone had the highest percent spent sitting and the lowest percent spent standing compared with other groups. However, control and DBY birds showed longer walking time than birds received AF only or DBY plus AF. Also, additional behavioral activities (preening, feeding and drinking) were significantly influenced by AF. Quails fed diet contaminated with AF had more preening time and short feeding time compared to other groups. No significant differences between treatments on drinking behaviour were found. These results indicate that, aflatoxin decreased activities and vitalities of the birds.

Our results clearly showed that the supplementation with dry baker's yeast could significantly counteract some of the toxic effects of aflatoxin in quail layers. This positive healthy effect of yeast supplementation was mainly attributed to yeast cell wall mannan-oligosaccharides (MOS) which is a natural adsorbent that effectively bind aflatoxin and undesirable bacteria in the gastro-intestinal tract (Devegowda et al., 1998; Schatzmayr et al., 2004). In addition live yeast (Saccharomyces cerevisiae) was found to increase the number and height of intestinal villi over in chicks, which increase the surface of nutrient absorption (AL-Homidan and Fahmy, 2007). 

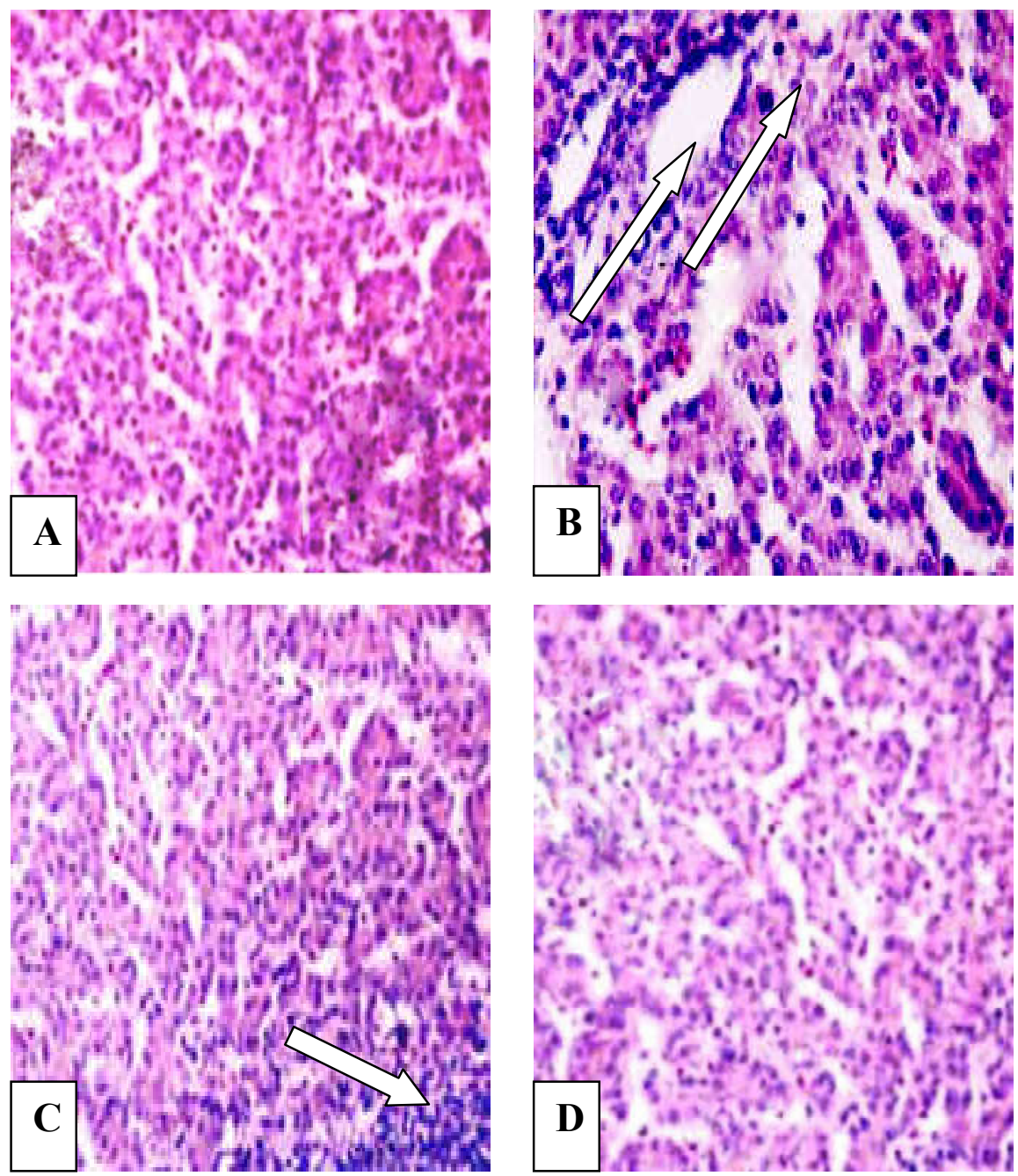

Fig. 1. Histopathological sections of the quails livers showing (A) normal liver tissue of the control group (B) degenerated liver tissue with fatty vacuolation of the toxicated group (C) liver tissue with minimal effect (inflammatory infiltration) of the group treated with toxin and dry baker's yeast (D) Intact liver tissue of the dry backer's yeast treated group. 
Table 5. Effects of dry baker's yeast (DBY) in feed on some behavioral activities (\%) of quail hens fed diet contaminated with aflatoxin (AF)

\begin{tabular}{|c|c|c|c|c|c|}
\hline \multirow[t]{2}{*}{ Items } & & \multicolumn{4}{|c|}{ Treatments } \\
\hline & & Control & $\begin{array}{c}\text { DBY } \\
(2 \mathrm{~g} / \mathrm{kg})\end{array}$ & $\begin{array}{c}\mathrm{AF} \\
(3 \mathrm{mg} / \mathrm{kg})\end{array}$ & $\begin{array}{c}\text { DBY }(2 \mathrm{~g} / \mathrm{kg}) \\
+\mathrm{AF}(3 \mathrm{mg} / \mathrm{kg})\end{array}$ \\
\hline \multicolumn{6}{|c|}{ Basic behavior (\%) } \\
\hline \multirow{3}{*}{ Standing } & Period I ${ }^{1}$ & $38.11 \pm 4.21^{\mathrm{a}}$ & $37.78 \pm 3.67^{\mathrm{a}}$ & $22.47 \pm 3.64^{b}$ & $40.56 \pm 4.12^{\mathrm{a}}$ \\
\hline & Period $\mathrm{II}^{2}$ & $40.34 \pm 3.42^{\mathrm{a}}$ & $41.62 \pm 4.31^{\mathrm{a}}$ & $20.72 \pm 4.12^{b}$ & $35.41 \pm 3.24^{\mathrm{a}}$ \\
\hline & Overall & $39.25 \pm 3.21^{\mathrm{a}}$ & $39.71 \pm 4.14^{\mathrm{a}}$ & $21.59 \pm 3.94^{b}$ & $37.98 \pm 3.62^{\mathrm{a}}$ \\
\hline \multirow{3}{*}{ Sitting } & Period I & $43.71 \pm 3.37^{\mathrm{c}}$ & $44.19 \pm 3.37^{\mathrm{c}}$ & $64.61 \pm 4.22^{\mathrm{a}}$ & $48.51 \pm 4.35^{b}$ \\
\hline & Period II & $39.51 \pm 4.23^{c}$ & $36.46 \pm 3.57^{\mathrm{c}}$ & $69.21 \pm 4.45^{\mathrm{a}}$ & $47.55 \pm 3.45^{b}$ \\
\hline & Overall & $41.61 \pm 4.62^{c}$ & $40.35 \pm 3.51^{\mathrm{c}}$ & $66.91 \pm 3.67^{\mathrm{a}}$ & $48.03 \pm 3.68^{b}$ \\
\hline \multirow{3}{*}{ Walking } & Period I & $18.18 \pm 3.64^{\mathrm{a}}$ & $18.03 \pm 3.64^{\mathrm{a}}$ & $12.92 \pm 3.41^{b}$ & $10.93 \pm 4.31^{b}$ \\
\hline & Period II & $20.16 \pm 2.61^{\mathrm{a}}$ & $21.96 \pm 2.97^{\mathrm{a}}$ & $10.08 \pm 2.64^{b}$ & $17.04 \pm 2.07^{\mathrm{ab}}$ \\
\hline & Overall & $19.17 \pm 3.01^{\mathrm{a}}$ & $19.97 \pm 3.12^{\mathrm{a}}$ & $11.50 \pm 2.82^{b}$ & $13.98 \pm 2.13^{\mathrm{ab}}$ \\
\hline \multicolumn{6}{|c|}{ Additional behavior (\%) } \\
\hline \multirow[b]{2}{*}{ Preening } & Period I & $17.12 \pm 2.34^{b}$ & $16.45 \pm 2.22 \mathrm{~b}$ & $21.34 \pm 2.14^{\mathrm{a}}$ & $18.91 \pm 2.45^{b}$ \\
\hline & Period II & $20.64 \pm 2.74^{b}$ & $19.26 \pm 2.12^{b}$ & $25.32 \pm 2.67^{a}$ & $20.43 \pm 2.27^{\mathrm{ab}}$ \\
\hline \multirow{4}{*}{ Feeding } & Overall & $18.87 \pm 2.03^{b}$ & $17.85 \pm 2.47^{b}$ & $23.33 \pm 2.08^{\mathrm{a}}$ & $19.67 \pm 2.14^{\mathrm{ab}}$ \\
\hline & Period I & $24.41 \pm 2.74^{\mathrm{a}}$ & $25.16 \pm 2.16^{\mathrm{a}}$ & $18.67 \pm 2.37^{b}$ & $23.45 \pm 3.72^{\mathrm{a}}$ \\
\hline & Period II & $27.32 \pm 2.12^{\mathrm{a}}$ & $28.92 \pm 3.16^{\mathrm{a}}$ & $16.31 \pm 2.25^{b}$ & $25.19 \pm 2.97^{\mathrm{a}}$ \\
\hline & Overall & $25.86 \pm 2.22^{\mathrm{a}}$ & $27.02 \pm 3.02^{\mathrm{a}}$ & $17.49 \pm 2.35^{\mathrm{b}}$ & $24.32 \pm 2.38^{\mathrm{a}}$ \\
\hline \multirow{3}{*}{ Drinking } & Period I & $4.19 \pm 1.48$ & $4.19 \pm 1.21$ & $4.87 \pm 3.22$ & $4.94 \pm 1.36$ \\
\hline & Period II & $3.75 \pm 1.22$ & $3.87 \pm 1.75$ & $2.98 \pm 1.36$ & $3.75 \pm 1.64$ \\
\hline & Overall & $3.95 \pm 1.34$ & $4.02 \pm 1.98$ & $3.91 \pm 1.09$ & $4.34 \pm 1.28$ \\
\hline
\end{tabular}

\section{CONCLUSIONS}

The results indicated that aflatoxin in a Japanese quail layers diet at a level of 3 $\mathrm{mg} / \mathrm{kg}$ of feed had negative effects on all productive, physiological and behavioral traits as compared with control during the experimental intervals. Also, showed that, all studied traits during the second experimental period were affected more than the first period. This clearly indicated that, the toxin had a cumulative effect on productive and physiological performance of the birds. On the other hand, the addition of DBY only at $2 \mathrm{~g} / \mathrm{kg}$ to quail layer diet enhanced some traits but had no significant differences compared to control. Moreover, the addition of DBY to laying quail's diet containing $3 \mathrm{mg} / \mathrm{kg}$ AF significantly improved all studied traits. Our findings strongly suggest that, the supplementation of laying quail's diet with the Saccharomyces cerevisiae had prophylactic effect on the performance of AF- treated birds via minimizing the harmful effects of toxin. 


\section{ACKNOWLEDGMENTS}

The authors would like to thank Prof. Dr. Mohamed E. Mady, Department of Animal Production, Faculty of Agriculture, University of Suez Canal for his efforts during this study.

\section{REFERENCES}

AL-Homidan, A. and M.O. Fahmy, 2007. The effect of dried yeast (Saccharomyces cerevisiae) supplementation on growth performance, carcass chemical analysis, immunity, ileum villi heights and bacterial counts of broiler chickens. Egypt. Poult. Sci., 27: 613-623.

Anderson, R.A., 1983. Detoxification of aflatoxin contaminated corn. In: Diener, U; Asquith, R and Dickens, J (Eds.), Aflatoxin and Aspergillus flavus in corn. Souther Cooperative Services Bulletin 279. Alabama Agricultural Experimental Station, Auburn University, Auburn, AL. 87-90.

AOAC, 1995. Official methods of analysis. $16^{\text {th }}$ ed. Vol (II), Chapter 49 (Natural toxins), Peter M. Health Protection Branch, Canada.

Arab Abousadi, M.L., E.L. Rowghani and M.H. Ebrahimi, 2007. The efficacy of various additives to reduce the toxicity of aflatoxin B1 in broiler chicks. Iranian Vet. Res. J., University of Shiraz, 8: 144-150.

Bancroft, J.D. and A. Stevens, 1990. Theory and practice of histology techniques. $3^{\text {rd }}$ ed. Churchill Livingstone, London.

Baptista, A.S., A.L. Abdalla, C.L. Aguiar, S.B. Ana Angelita, M. David, A.C. Zampronio, D.S. Pires, E.M. Glória, M.A. Calori-Domingues, J.M. Walder, M.R. Vizioli and J. Horii, 2008. Utilization of diets amended with yeast and amino acids for the control of aflatoxicosis. World J. Microb. \& Biotech., 24: 2547-2554.

Betina, V., 1989. Aflatoxins, sterigmatocystins and versicolorins. In: Mycotoxins: Chemical, Biological and Environmental Aspects. Elsevier, Amsterdam-OxfordNew York-Tokyo. 115-50.

Broomhead, J.N., D.R. Ledoux, A.J. Bermudez and G.E. Rottinghaus, 2002. Chronic effects of fumonisin B1 in broilers and turkeys fed dietary treatments to market age. Poult. Sci., 81: 56-61.

Chang, C.F. and P.B. Hamilton, 1982. Experimental aflatoxicosis in young Japanese quail. Poult. Sci., 61: 869-874.

Devegowda, G., M.V. Radu, A. Nazar, H.V. Swamy, 1998: Mycotoxin picture worldwide: Novel solutions for their counteraction. Proceedings of Alltech's 14th Annual Symposium: 241-255.

Doerr, J.A. and M.A. Ottinger, 1980. Delayed reproductive development resulting from aflatoxicosis in juvenile Japanese quail. Poult. Sci., 59: 1995-2001.

Edds, G.T. and R.R. Bortell, 1983. Biological effects of aflatoxin in poultry. In: Diener, UL; Asquith, RL and Dickens, JW (Eds.), Aflatoxin and Aspergillus flavus in corn. Souther Cooperative Services Bulletin. 279. Alabama Agricultural Experimental Station, Auburn University. AL. 55-61.

Glahn, R.P.; K.W. Beers, W.G. Bottje, R.F. Wideman, W.E. Huff and W. Thomas, 1991. Aflatoxicosis alters avian renal function, calcium and vitamin D metabolism. J. Toxicol. Environ. Health. 34: 309-321. 
Gokhan E., C.L Bilal, K.G. Berrin, A. Ayhan, N.K. Ayse and B. Latife, 2004. Evaluation of aflatoxin toxicity in Japanese quails given various doses of hydrated sodium calcium aluminosilicate. Bull Vet Inst. Pulawy. 48: 511-517.

Gokhan E., E. Dinc, A. Mehmet, K. Erdal, O. Meral and O. Zafer, 2006. Efficacy of dietary sodium bentonite against subchronic exposure to dietary aflatoxin in broilers. Bull Vet. Inst. Pulawy. 50: 107-112.

Hawkey, C.M. and T.B. Dennett, 1989. A color atlas of comparative veterinary hematology. Wolf Publishing Limited, London, England.

Johri, T.S., R.C. Agrawal and V.R. Sadagopan, 1990. Effect of low dietary levels of aflatoxin on laying quail (Coturnix coturnix japonica) and their response to dietary modifications. Indian J. Anim. Sci., 60: 355-359.

Karaman, M., H, Basmacioglu, M. Ortatati and H. Oguz, 2005. Evaluation of the detoxifying effect of yeast glucomannan on aflatoxicosis in broilers as assessed by gross examination and histopathology. Br. Poult. Sci., 3: 394-400.

Kemal, C., D. Muzaffer, S. Türker, 2003. Reduction of toxic effects of aflatoxin B1 by using baker yeast (Saccharomyces cerevisiae) in growing broiler chicks diets. R. Bras. Zootec., 32: 615-619.

Kubena, L.F., R.B. Harvey, W.E. Huff, D.E. Corrier, T.D. Phillips and G.E. Rottinghaus, 1990. Efficacy of a hydrated sodium calcium alumino-silicate to reduce the toxicity of aflatoxin and T-2 toxin. Poult. Sci., 69: 1078-1086.

Leeson, S., G. Diaz and J.D. Summers, 1995. Poultry metabolic disorders and mycotoxins. (1st. Edn.), Canada University Books, Ont., 248- 279.

Miazzo, R., C.A. Rosa, E.C. DeQueiroz, C. Magnoli, S.M. Chiaccnieva, C. Palocio, M. Saenz, A. Kikot, E. Basaldella and A. Dalcero, 2000. Efficacy of synthetic zeolite to reduce the toxicity of aflatoxin in broiler chicks. Poult. Sci., 79: 1-6.

Muzaffer, D., C. Kemal and O. Ferda, 2003. Effects of vitamin A supplementary in the feed to reduce toxic effects of aflatoxin B1 on Japanese quails (Coturnix coturnix Japonica). Int. J. Poult. Sci., 2: 174-177.

National Research Council, 1994. Nutrient Requirements of Poultry. 9th rev. ed. National Academy Press, Washington, DC.

Ogido, R., C.A. Oliveira, I.D. Ledoux, G.E. Rottinghaus, B. Correa, P. Butkeraitis, T.A. Reis, E. Goncales and R. Albuquerque, 2004. Effects of prolonged administration of aflatoxin B1 and fumonisin B1 in laying Japanese quail. Poult. Sci., 83:1953-1958.

Oliveira, C.A., J.F. Rosmaninho, P. Butkeraitis, B. Correa, T.A. Reis, J.L. Guerra, R. Albuquerque and M.E. Moro, 2002. Effect of low levels of dietary aflatoxin B1 on laying Japanese quail. Poult. Sci., 81:976-980.

Parlat, S., 2003. Biological suppression of aflatoxicosis in Japanese quail (Coturnix coturnix japonica) by dietary addition of yeast (Saccharomyces cerevisiae). Research in Vet. Sci., 71: 207-211.

Raper, K.B. and D.I. Fennel, 1965. the genus Aspergillus, Williams \& Wilkins, Baltimore. 686.

Richard, J.L., J.A. Bennett, B.F. Ross and B.E. Nelson, 1993. Analysis of naturally occurring mycotoxins in feed stuffs and food. J. Anim. Sci., 71: 2663-2574.

Santin, E.I, A.C. Paulillo, E.L. Krabbe, A.C. Alessi, W.J. Polveiro, A. Maiorka, 2003. Low level of aflatoxin in broiler at experimental conditions use of cell wall yeast as adsorbent of aflatoxin. Brazil Arch. Vet. Sci., 8: 51-55. 
SAS Institute, 1998. SAS statistical guide for personal computer, SAS Institute Inc. Cary, NC.

Sawhney, D.S., D.V. Vadehra and R.C. Baker, 1973. Aflatoxicosis in the laying Japanese quail (Coturnix coturnix japonica). Poult. Sci., 52: 465-473.

Schatzmayr, D., S. Nitsch, E.M. Binder, M. Taubel, A. Loibner and G. Schatzmayr, 2004. Detoxification of mycotoxins. World Nutrition Forum, 128-129.

Stanley, V.G., M. Winsman, C. Dunkley, T. Ogunleye, M. Daley, W.F. Krueger, A.E. Sefton and A. Hinton, 2004. The impact of yeast culture residue on the suppression of dietary aflatoxin on the performance of broiler breeder hens. J. Appl. Poult. Res., 13: 533-539.

Tietz, N.W., 1982. Fundamental of clinical chemistry. Edition by Norbert Sanrders Company, Philadelphia, USA.

Tollba, A.A. and A.H. El-Nagar, 2008. Increasing stocking density of Egyptian local hens by: 1-Antioxidants and live yeast. Egypt. Poult. Sci., 28: 575-598.

West, S., R.D. Wyatt and P.B. Hamilton, 1973. Improved yield of aflatoxin by incremental increases in temperature. Appl. Microbiol. 25: 1018-1019.

Winderobe, M.M., 1965. Clinical Hematology. Lea and Febiger, Philadelphia, USA.

Yildirim, S. and S. Parlat, 2003. Effects of dietary addition of live yeast (Saccharomyces cerevisiae) on hatching traits, testis and ovary weights of Japanese quail (Coturnix coturnix japonica) in aflatoxicosis. Arch. Geflügelk., 67: 208-211. 


\title{
تأثير استخدام خميرة الخباز الجافة على تثبيط تأثيرات الأفلاتوكسين فى العليقة على بعض

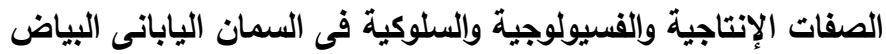

\author{
حسن عبد النفار خليل '، محمد عبد الرازق'
}

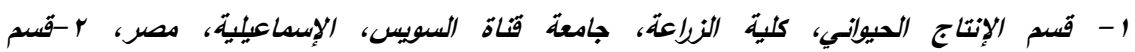

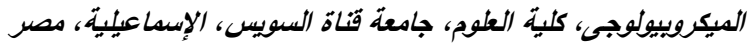

أجريت هذه الدراسة لمعرفة تأثير خميرة الخبازالجافة (Saccharomyces cerevisiae) على تثبيط

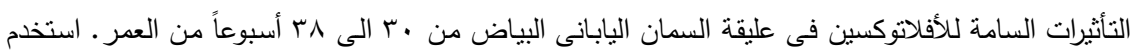

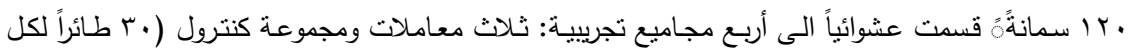
مجموعة وكل مجموعة وزعت على ثلاث مكررات). الدجموعة الأولى كانت مجموعة المقارنة (الكنترول) والتى التى

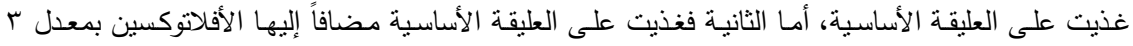

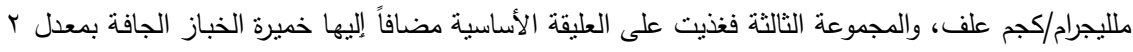

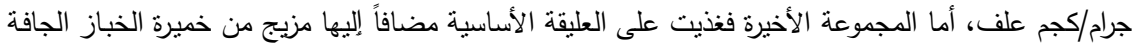

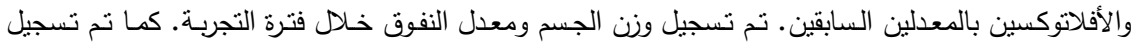

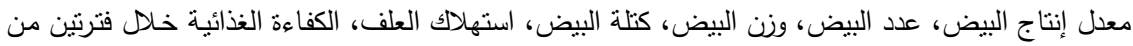

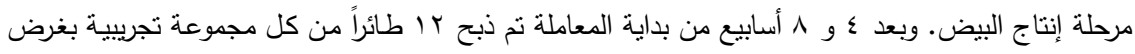

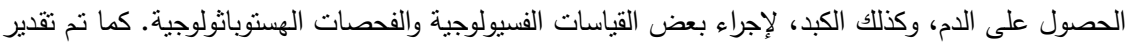

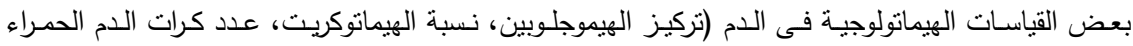

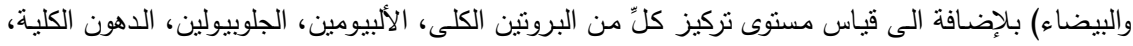

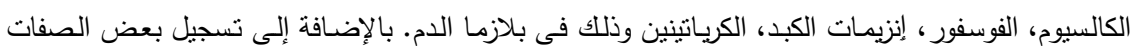

السلوكية للطيور خلال فترة التجربة. وقد أكدة الننائج أن للأفلاتوكسين تأثيرات سليبة على الصفات الإنتاجية والفسيولوجية والسلوكية خلال فترتى الإنى

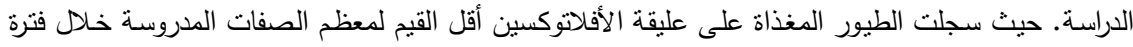

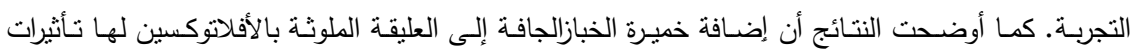
إيجابية وملحوظة على خفض سمية الأفلاتوكسين، حيث سجلت الطيور المغذاة على عليقة مضاف إليها

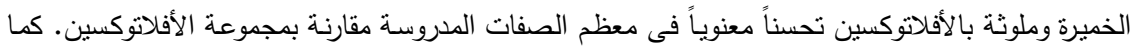

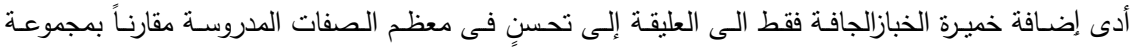

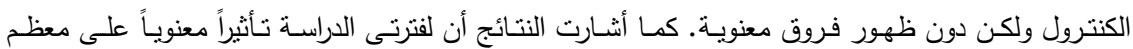
الصفات المدروسة خاصاً فى مجموعة الأفلاتوكسين.

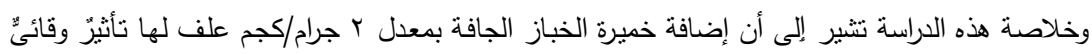

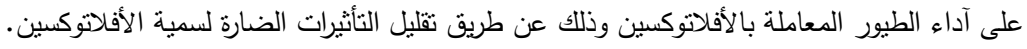

